\title{
Society and brain: A complementary approach to Thorstein Veblen's conspicuous consumer based on Tibor Scitovsky's neuropsychology
}

A sociedade e o cérebro: Uma abordagem complementar ao consumidor conspícuo de Thorstein Veblen com base na neuropsicológica de Tibor Scitovsky

Felipe Almeida

Universidade Federal do Paraná

\begin{abstract}
The goal of this study is to complement Thorstein Veblen's conspicuous consumer approach to economics with Tibor Scitovsky's neuropsychological analysis. This is undertaken by exploring the psychological basis of both theories. Veblen's conspicuous consumer emulates the leisure class, which consumes what can be understood as the best goods of a society. These goods are associated with the concept of social satisfaction rather than physical satisfaction. Veblen's conspicuous consumer decision making is introduced here according to insights from the American pragmatic school of philosophy. On the other hand, Scitovsky introduced elements of neuropsychology to economics using an interdisciplinary approach that was understandable to economists as he sought a better comprehension of consumers' decision making. Scitovsky's psychologicaleconomics approach was inspired by studies from Daniel Berlyne and Donald Hebb. In considering Scitovsky's approach, this study contributes to understanding the decision making of Veblen's conspicuous consumer.
\end{abstract}

\section{Keywords}

Thorstein Veblen; Tibor Scitovsky; conspicuous consumption; institutional economics.

JEL Codes B15; B52.

\section{Resumo}

O objetivo desse artigo é apresentar a abordagem neuropsicológica de Tibor Scitovsky como complementar ao consumidor conspicuo de Thorstein Veblen. Essa aproximação é realizada através da análise da base psicológica de ambas as teorias. O consumidor conspicuo de Veblen emula a classe ociosa que consome o que pode ser compreendido como os melhores bens presentes na sociedade. Essa lógica está mais associada a um conceito de satisfação social do que a uma satisfação física. Em busca de destacar o conteúdo psicológico do consumidor conspicuo de Veblen, esse artigo apresenta a tomada de decisão desse consumidor de acordo com a lógica da filosofia pragmática norte-americana. Por sua vez, Scitovsky introduziu elementos da neuropsicologia à economia através de uma abordagem interdisciplinar, compreensivel pelos economistas, em busca de uma melhor compreensão da tomada de decisão do consumidor. A abordagem psicológico-econômica de Scitovsky foi inspirada pelos estudos de Daniel Berlyne e de Donald Hebb.

\section{Palavras-chave}

Thorstein Veblen; Tibor Scitovsky; consumidor conspicuo; economia institucional.

Códigos JEL B15; B52. 


\section{Introduction}

The intellectual environment of economics is dominated by the rational decision making of consumers based on given tastes and preferences and static, teleological and individualistic analysis. Very few studies offer an alternative, but this study relies on two alternatives. One is Thorstein Veblen's The Theory of the Leisure Class and the other is Tibor Scitovsky's The Joyless Economy. Veblen was a founding father of original, or old, institutional economics, which was a prominent branch of economic science during the first decades of the 20th century (Hodgsom, 2004; Rutherford, 2011). It is widely recognized that The Theory of the Leisure Class (Veblen, 1899 ) is one of the first books on institutional economics. It introduced to economic science a consumer whose decisions rely on habits, institutions and emulation of higher social classes.

In Veblen's approach, the evolution of predatory habits of life and exploitation generates a stratified society, in which there is a higher social class in material terms, an institution called the leisure class. The leisure class does not perform industrial tasks and consumes what can be understood as the best goods in a society. Goods associated with the leisure class are regarded as honorific and noble by other members of the society. This is the foundation of 'emulation' of Veblen's conspicuous consumer. Goods consumed by the leisure class are not a source of physical satisfaction but rather one of social satisfaction, which is a key subject of Veblen's conspicuous consumer. In this unconventional approach, Veblen designed conspicuous consumer decision making to deal with psychological, social, anthropological and economic issues.

The contribution of Scitovsky to the economic analysis of consumers' decision making was introduced in a complete version in his The Joyless Economy (Scitovsky, 1976). Throughout the 1970s, Scitovsky published some studies about consumers' decision making, which helped him to write The Joyless Economy. His studies during the 1980s can be understood as applications of insights from The Joyless Economy. Hence, in terms of consumers' decision making, The Joyless Economy is unquestionably Scitovsky's main contribution and most mature research. As stated by Hirschman (1982), Scitovsky made an original and stimulating effort to improve economic understanding about consumer satisfaction and preference formation. 
According to Scitovsky (1976), The Joyless Economy analyzes the psychology of human motivation and satisfaction in order to explain why consumers may be unsatisfied even in periods of prodigious prosperity. The great prosperity of the US in the 1970s puzzled Scitovsky and motivated him to write the book. Scitovsky was worried about the economic system that consumers were moving into and wanted to understand how consumers could be unsatisfied, despite economic prosperity. Despite its importance as an unconventional approach to consumers' decision making, the contribution of Scitovsky's The Joyless Economy was obscured by its remoteness from both traditional economists and by opponents of homo economicus or the rational man (Friedman; McCabe, 1996). Sen (1996) puts this argument in a political perspective: Scitovsky's approach fully pleased neither the left nor the right. However, his approach is much more descriptive than critical, which reduces the emphasis of a possible political perspective.

The main goal of this study is to complement Veblen's conspicuous consumer approach with Scitovsky's neuropsychological analysis. The key issue is to offer a neuropsychological basis to Veblen's conspicuous consumer in order to enrich the institutionalist explanation. To achieve that goal, this study explores the psychological basis of both Veblen's and Scitovsky's approaches as secondary and supporting goals. It is recognized that psychological insights into Veblen's theory rely on the American pragmatic school of philosophy (Edgell; Tilman, 1989; Twomey, 1998). Hence, this study introduces a psychological reading of Veblen's conspicuous consumer, based on the writings of Charles Peirce, John Dewey and William James, considered to be the most important classical pragmatists. Scitovsky introduced elements of neuropsychology to economics in an interdisciplinary approach that was understandable to economists. According to Scitovsky (1985), his psychological-economics approach was inspired by the neuropsychology of Daniel Berlyne and Donald Hebb. Hence, Berlyne's and Hebb's studies are considered in this study.

The rest of this paper is as follows. Section Two presents Veblen's conspicuous consumer decision making by stressing the role of the American pragmatic school of philosophy as its psychological base. Section Three stresses elements from Scitovsky's consumer decision-making perspective by emphasizing the neuropsychology of Berlyne and Hebb. Section Four builds bridges between the two approaches; it offers a perspective on how elements of the psychology of Scitovsky's consumer decision-making ap- 
proach can complement Veblen's conspicuous consumer approach. Some final comments conclude the paper in Section Five.

\section{Pragmatic philosophy and Veblen's conspicuous consumers}

In general, Veblen's approach is about institutions mediating the evolution of people's thoughts in a society and the impact on behavior of this evolution of thoughts. By evolution, Veblen does not necessarily mean improvement, but rather cumulative modification. Accordingly, social organization refers to a scheme of institutions (Veblen, 1898) and institutions are outgrowths of habits (Dewey, 1921; Veblen, 1909; 1919). This conceptualization is strong in Veblen's theory. Hodgson (1998) defines what can be understood as the Veblenian concept of habit as a largely non-deliberative and self-actuating propensity to engage in a previously adopted pattern. Hence, a key issue to understand conspicuous consumers' decision making is to comprehend how that pattern is recognized, learned and adopted. The search for answers leads us to the connection between Veblen's conspicuous consumer decision making and American pragmatism.

In order to understand the recognition, learning and adoption of habits, our discussion is led to the reasons for consumers engaging in behavioracquisition of goods. If we focus on the basic motivation for behavior, philosophers and psychologists usually identify instincts as behavioral incentives. Veblen introduces his own perspective of an instinctive approach to the conspicuous consumer. For Veblen (1914), inner impulses to action are tropism or reflex. Philosophers and psychologists usually use the term 'instinct' for what Veblen calls tropism or reflex. Veblen uses the term 'instinct' differently than in the usual sense. According to Veblen, cognitive abilities, particular perceptions and even intelligence are part of instincts (Cordes, 2005). Consequently, the Veblenian perspective of instincts takes into account the relationship between consumers and the environment around them, which differs from the common sense or usual conceptualization. For Veblen, what is learned in the interaction with the external world can comprise an instinct. In order to avoid a conceptual mess, the term 'instinct' is used in this study as defined by Veblen. The 
usual meaning of conceptualization is termed 'inner impulse'. ${ }^{1}$

Taking inner impulses and instincts into account, it can be argued that William James' theory has a significant place in Veblen's approach. ${ }^{2}$ As emphasized by James (1890b), relationships between inner impulses and goods are built according to a process called appropriation. Through this process, consumers learn how to connect goods to inner impulses in order to satisfy these impulses. An inner impulse is a power of constant impact that is impossible to escape. The pressure to behave is common in every inner impulse. Decision makers desire responses to inner impulses; once responded to, an inner impulse stops causing pressure and a sensation of satisfaction is felt by the decision maker. For James (1890b), appropriation as the response to consumers' inner impulses is a way for consumers to achieve the satisfaction to be free from inner impulses. ${ }^{3}$

1 Taking Veblen's concept of instinct into account is not a simple task. The complexity is because of the difference between Veblen's concept of instincts and habits. Veblen defined instincts as holding social elements as well as being an internal pressure to behave (Veblen, 1914). Waller (2013) and Almeida (2014, 2015) recently have two different approaches to this issue. The former stresses that Veblen dealt with two concepts of instincts: simple and complex instincts. A simple instinct is reflex or tropism and a complex instinct is habit (Waller, 2013). This terminology seems to have its origins in the conceptual mess around Veblen's concept of instinct, as he used 'habit' and 'instinct' as similar or one and the same, especially in Veblen (1914). Consequently, Waller (2013) offered a terminology that supports the understating of Veblen's concepts of instincts and habits-complex instinct-in order to differentiate them from tropism and reflex-simple instinct. However, a misunderstanding occurs as both instincts and habits are classified as complex. Hence, Waller (2013) does not answer the question: what is the difference between the instinct of workmanship and an emulative habit? Almeida (2014, 2015) offers an answer by introducing another perspective of the classification of Veblen's concepts of instinct. What Waller (2013) refers to as 'simple instinct', Almeida (2014, 2015) calls 'inner impulse'. In addition, Almeida $(2014,2015)$ stresses that Veblen's concept of instinct means a habit deeply embedded in decision making, and hence, a Veblenian instinct would be a deeper habit. In summary, for Almeida (2014, 2015), there are three decision-making elements in the Veblenian perspective: inner impulses, instincts, and habits. A problem arises when someone puts the usual concept of instinct aside Veblen's. The usual concept of instinct means Veblen's inner impulse whereas Veblen's instinct means something different, as it regards a habit strongly assimilated by decision makers. This study follows Almeida's classification.

2 Nevertheless, it is important to stress that James does not share Veblen's definition of instinct unquestionably. On one hand, this is because, according to James (1890b, 383), 'instinct [inner impulse] is usually defined as the faculty of acting in such a way as to produce certain ends, without foresight of the ends, and without previous education in the performance'. On the other hand, James emphasizes that every living creature is a bundle of habits, but in the case of human beings, the acquisition of habits is based on education. In addition, habits learned by education are instincts, or ' $[t]$ he habits to which there is an innate tendency' (James 1890a, 104). Even though this is a 'partial sharing' of the Veblenian concept, it does not make it impossible to rely on James to discuss Veblen's perspective.

3 As this section intends to highlight, Veblen's theory is not only about ways and meanshabits and institutions - to make inner impulses stop causing pressure. It is also mainly about how ways and means become the actual source of satisfaction for the conspicuous consumer. 
As stated by James (1890b), appropriation is unrelated to the essence of inner impulses. Appropriation is the connection between inner impulses and goods. It is a way to secure the satisfaction generated by getting rid of an impulse to behave by behaving (James, 1890b, p.423). Hence, it is possible to argue that appropriation means there is an impulse-good connection. Regarding Veblen's notion of instinct, it is important to highlight that appropriation is already part of instincts. From Veblen's perspective, instincts are composed of not only inner impulses, but also practices and impulse-goods connections. ${ }^{5}$ An essential point of Veblen's conspicuous consumer is that impulse-goods connections are social issues - hence, satisfaction is a social subject in Veblen's analysis. This issue is discussed in detail later in Section Two.

Dispositions to behave led by the appropriation process are learned by the interaction between the consumer and the decision-making environment (Dewey, 1910a, 1921). The environment is perceived by consumers through the behavior of others. People learn how to put inner impulses into practice by understanding others' disposition to behave. When there is some difficulty in decision making, observation is the first step to deal

4 This may suggest that the only source of satisfaction for a consumer is the cessation of the pressure of inner impulses to consume, but from Veblen's perspective, this is quite wrong. According to Veblen (1899), institutional pressures are the important pressures to be attended to in order to satisfy a consumer. In addition, taking into account that this study refers to satisfaction as a result of an inner impulse, it is important to highlight that Veblen rejects the logic of utilitarian pleasure-pain decision making (Argyrous; Sethi, 1996; Veblen, 1898, 1909). The passage below is quoted usually in the context of strong disapproval of the traditional economics-based approach to decision making: "The hedonistic conception of man is that of a lightning calculator of pleasures and pains, who oscillates like a homogeneous globule of desire of happiness under the impulse of stimuli that shift him about the area, but leave him intact. He has neither antecedent nor consequent. He is an isolated, definitive human datum, in stable equilibrium except for the buffets of the impinging forces that displace him in one direction or another... The later psychology, re-enforced by modern anthropological research, gives a different conception of human nature. According to this conception, it is the characteristic of man to do something, not simply to suffer pleasures and pains through the impact of suitable forces. He is not simply a bundle of desires that are to be saturated by being placed in the path of the forces of the environment, but rather a coherent structure of propensities and habits which seeks realization and expression in an unfolding activity."

(Veblen, 1898, p.389-390). Veblen believed that an individualistic pleasure-pain reading of human behavior is not enough. From a Veblenian perspective, the socialization process adds other layers to decision making.

5 Veblen stresses some specific concepts of instinct. The main concepts are the instinct of workmanship, parental bent and idle curiosity. However, considering the goal of this study, Veblen's specific concepts of instinct are not central to the analysis. The central issue is Veblen's perspective on instincts and the manner in which they can influence consumer decision making. For more information about the instinct of workmanship, parental bent and idle curiosity, see Latsis (2009). 
with this difficulty (Dewey, 1910a). Other people introduce consumers to possible paths of behavior by offering for observation their appropriation and consequent impulse-goods connections. Dewey (1921, p.89) highlights this logic, affirming that "ii]mpulses although first in time are never primary in fact; they are secondary and dependent', as other people show consumers how to deal with the external world. 'The meaning of native activities is not native; it is acquired' (Dewey, 1921, p.90). At the end of this process, socially created habits are formed.

A habit means an impulse-good connection that has been learned and is reinforced by interaction with others. If an impulse-good connection offers satisfaction to consumers through time, it may stay for a long time. This continuous satisfaction implies reinforcement of the impulse-goods connection. Hence, behavior related to the impulse-good connection is more likely to recur. According to James (1890a), any sequence of behavior that is repeated frequently tends to be preserved. In addition, observation of the appropriation process of others does not take place only when the observer is building an impulse-good connection. Usually, the appropriation process of others is observed and the recurrent observation reinforces impulsegoods connections. A reinforced impulse-goods connection implies disseminated behavior in a society. In this case, there are more models of behavior to be observed and more consumers would try to behave accordingly. Some would succeed and become models themselves. The consequence is a snowball effect of models that culminates in socially spread habits.

James (1890b) adds a key subject for following this logic, namely, that habits are able to inhibit inner impulses: "[a] habit, once grafted on an instinctive tendency, restricts the range of the tendency itself, and keeps us from reacting on any but the habitual object ...' (James, 1890b, p.395) and '[i]n civilized life the impulse to own is usually checked by a variety of considerations, and only passes over into action under circumstances legitimated by habit and common consent' (James 1890b, p.422). James (1890b) stresses that appropriation is associated with habitualization of how to put impulses into practice, in other words, how to create or support an impulse-goods connection.

Dewey (1921, p.125) contributes to this discussion by affirming that ' $[\mathrm{m}] \mathrm{an}$ is a creature of habit, not of reason nor yet of instinct [inner impulse]'. This relationship between inner impulses and habits reinforces that, in Veblen's approach, there are no 'pure impulses' but only habits built 
under influence of association with others who already hold habits (the evolution of habits in a society relies on this logic). ${ }^{6}$ The use of such a concept of habits is a strong influence on the American pragmatist school of philosophy in Veblen's writing, especially on Dewey, who is emphatic in his definition of habit: '... we must protest against the tendency in psychological literature to limit its meaning to repetition' (Dewey, 1921, p.41).?

In Veblen's theory, acquiring habits is not only a way to incorporate the environment into the consumer's logic in order to help satisfy inner impulses, but the environment also creates impulses to consume. Hence, there are inner impulses and social impulses to consume. A key issue of Veblen's theory - as well as the writings of James and Dewey - is that social impulses overlap inner impulses. Following this standpoint, Dewey (1910a) affirms that habits are interactions of elements given by the make-up of a decision maker with elements provided by the biased traditions of the external world. Habits are the influence of past knowledge on current knowledge in such a manner that the past conditions, but does not determine present decision making.

Biased tradition and past knowledge manifest themselves in institutions, and their association with habits relies on institutions as outgrowths of habits, as stated by Veblen's theory. Consequently, impulse-goods connections established by habitualization take place by the accepted standard tradition contained in an institution (Peirce, 1877). Impulse-goods connections show the continuing institutionalized tradition of a society under the semblance of acquiring goods. However, in an institutionalized world, appropriation is not associated objectively to the connection between an inner impulse to consume and a good to satisfy this impulse. In a decision-making environment composed of institutions, appropriation relies on a connection between inner impulses and concepts of goods. Goods carry the meaning that the biased tradition of society gives to them

6 In addition, Peirce (1877) reinforces this issue by highlighting that the logic of individualistic trial and error is not the procedure by which a consumer learns how to behave, which is social learning. Behavior that occurs in a society is always shared (Dewey, 1910b). In Dewey's words: "[i]t is not an ethical "ought" that conduct should be social. It is social, whether bad or good' (Dewey, 1921, p.17, emphasis in the original).

7 For Dewey (1921), repetition is not even the essence of habit. However, repetition can be an incident of many habits. An individual who is looking for a healthier life provides an example of habit that is not associated with repetition. Foregoing sugar, fatty food and smoking can be habits acquired by the individual. These habits do not imply repetitive behavior. For Dewey (1921), the essence of a habit is a predisposition to ways or modes of behavior. 
- their concepts. Concepts of goods are shared collectively and learned through habits and institutions. That is why habits and institutions are stronger than inner impulses in Veblen's decision-making approach.

Veblen (1899) stresses a particular type of institution as extremely important for the establishment of the concepts of goods, namely, the leisure class, which is an upper socioeconomic class, particularly in material terms. As stressed by Veblen (1899), the leisure class has developed best in modern societies because in such societies, distinctions between classes and classification of groups are observed clearly. For Veblen (1899), the evolution of culture generated a leisure class and related social classification around the same time as the beginning of the private ownership of goods. The central point is that the leisure class and ownership of goods emerge simultaneously. Both arise from the desire of successful people to exhibit their prowess. Hence, ownership of goods is not just about property or personal consumption; it is also about convention and demonstrating the use of these goods.

Veblen (1899) stresses that in a society in which almost all goods are private property, the necessity for members of the poorer class to earn their livelihood is a powerful and constant incentive. As soon as their subsistence is guaranteed, emulation becomes a key guideline for behavior (Veblen, 1899). The existence of the leisure class, in Veblen's theory, is not only about collective classification, but is also mainly about social selection. This social selection occurs based on the capacity to emulate the way of life of the leisure class. Dewey $(1921,1939)$ reinforces this point by stressing that there is satisfaction that comes from the sense of union with others. This satisfaction comes from what is communicated to others. For Peirce $(1868,1877)$, the feeling of belonging to a community is an indication that some habit has been established in consumers' nature that guides their behavior. The conspicuous consumer's satisfaction is associated with the institutionalized sense of social fulfillment (Dewey, 1930).

For Veblen (1899), this social fulfillment relies on the consumption of concepts of goods by their status content guided by the emulation of the leisure class. According to Dewey (1934), status relies on a 'long history of unquestionable admiration', which is part of institutionalized concepts. When a good achieves status, it signifies that its concept respects an esthetic that has been established socially and evolutionarily (Dewey, 1934). Hence, concepts of goods are differentiated by their status content. For De- 
wey (1910a), status, which is associated with the position that consumers think they occupy in a society, plays a key role in their decisions. Goods regarded as objects acquired by the leisure class become a strong signal of success because status is attached to the concepts of goods. ${ }^{8}$ Veblen's conspicuous consumer always looks to consume like the higher social class and is possibly seeking to achieve the same 'consumption success' as the leisure class. By emphasizing the socially emulative logic of consumption mediated by the leisure class, Veblen's approach to consumption relies strictly on its feature of conspicuousness. Thus, conspicuous consumption can be understood as wasteful monetary expenditure motivated by social esteem and selection.

\section{Neuropsychology and Scitovsky's joyless economy}

Like Veblen, Scitovsky does not rely on inner impulses playing a key role in the basic motivation for consumers' behavior (Scitovsky, 1976). However, Scitovsky does not share Veblen's unusual concept of instincts. For Scitovsky (1976), instincts are inner impulses. Nevertheless, Scitovsky does not follow an inner impulse psychological approach. He understood that approaches of inner impulses led psychology to analyses of biological reductionism and 'black box' instrumentalism. Scitovsky's approach relies on neuropsychology. Neuropsychology can be understood as the psychological perspective of the neurophysiology, which takes arousal into account in order to build decision-making studies. Arousal corresponds to a level of excitement and alertness; it is a power to excite the nervous system and, consequently, to influence consumers to behave (Berlyne, 1973; Scitovsky, 1976).

8 With regard to this point of analysis, it is important to add features of what the Veblenian concept of goods is. This concept of goods relies on the feature of conspicuousness, which means spending money on goods in order to display wealth to other members of society (Trigg, 2001; Veblen, 1898). Shipman (2004) emphasizes that the central aspect of Veblen's conspicuous consumption is the acquisition of goods according to 'waste' despite 'taste'. Waste can be understood as taste that involves social learning through the institution of the leisure class (Ramstad, 1998). The conspicuous consumer buys goods for their status, based on wastefulness, and thus, pays for particular features of these products. By this logic, there is an understanding of how to seek status that can be expressed in concrete, objective ways to emulate the behavior of the leisure class by buying their goods (Veblen, 1899). Through the capacity to increase the conspicuousness of the conspicuous consumer's acquisition of the concept of goods, she/he shows her/his social power in order to survive in social selection. 
As stated by Berlyne (1973), the term 'arousal' usually means 'level of arousal'. Level of arousal depends on the stimulus that the central nervous system receives from the outside world (i.e., everything that is not a physical part of the decision maker) and the organism (physical internal stimulation). The organism is the focus of inner impulse approaches. The outside world is the usual analytical object of arousal theories. ${ }^{9} \mathrm{Hebb}$ (1955) and Berlyne (1960) associate arousal and behavior by affirming that the motivation to behave results from the arousing of behavior. The process by which behavior is motivated relies on changing the level of arousal (Hebb, 1955). In order to avoid misunderstanding of terminology, the term 'arousal' hereafter refers to 'level of arousal'.

Following Scitovsky's analytical perspective, arousal motivates consumers to acquire goods. A central issue of Scitovsky's theory is that different goods imply diverse arousal and the arousal capacity of goods means different levels of satisfaction for the consumer. Scitovsky $(1976,1985)$ emphasizes two different levels of satisfaction-pleasure and comfort. The former provides higher satisfaction than the latter. The reason is that pleasure is a result of heightened arousal and comfort refers to the maintenance of lower arousal. The changing of pleasure by arousal relies first on an achievement. Then, the maintenance of a lower arousal is associated with the support of an achievement previously attained.

Scitovsky's concept of pleasure is associated with the concept of novelty. As stated by Scitovsky $(1976,1985)$, novelty is essential for mental stimulation. The arousal effect of novelty is pleasurable. In order to be pleasurable, novelty must be different to what is familiar, but not too different. There must be some familiarity in order for the consumer to understand the novelty and insert it in her/his decision making. According to Berlyne (1960), even a novelty must find a place in consumers' decision making in order to be perceived by consumers' logic. This place usually relies on partial knowledge of the novelty. For this logic to hold, goods must have similarities, which is not a strong hypothesis taking modern societies into account. As soon as the novelty becomes too familiar, it is less satisfactory.

9 As Section Two introduced, Veblen analyzes the relationship between the decision maker and the outside world in his approach to conspicuous consumers' decision making. Hence, how consumers deal with the external world, represented by goods, is the key connection between Veblen's conspicuous consumer and Scitovsky's approach. 
Considering the arousal perspective, the familiarity of the novelty relies on the fact that high arousal is not necessarily always pleasurable. A high degree of newness implies too much arousal, which is not pleasurable to consumers. Too much arousal is unpleasant because it implies anxiety and tension associated with confused decision-making logic, or too much arousal. However, too little arousal is also unsatisfactory because it culminates in a desire for more - a low level of novelty implies boredom, or too little arousal. Hence, consumers try to avoid too much or too little arousal (Hebb, 1955). An intermediated level of novelty is the most satisfactory (Scitovsky, 1976, 1981).

For Scitovsky (1976), this perspective of pleasure and comfort has important analytical consequences: it explains the fleeting nature of satisfaction and it explains why the achievement of goals that were not achieved before is more satisfying than the achievement of the same goal one more time. In addition, according to Scitovsky (1976), there are two sources of comfort. One is the use of increased affluence for continuous satisfactionmaintaining comfort after pleasure. The other is escaping boredom. When a consumer is entirely comfortable, a simple change in the acquisition of goods-a new achievement-can be arousing (because the consumption of a good for the first time is pleasurable). Scitovsky (1976) stresses that when consumers feel only the satisfaction of comfort, they feel a necessity to increase arousal.

Hirschman (1982) stresses that Scitovsky's approach takes into consideration that comfort is the enemy of pleasure. Hence, every good that guarantees comfort also assures a low level of satisfaction. With regard to the same good, this culminates in pleasure only once, when the good is consumed for the first time. Once the good is 'turned on', only comfort is achievable. Hirschman (1982) affirms that a good that generates comfort is a good taken for granted. The consumer knows what the good generates and the consumer is comfortable with the result. Scitovsky's (1976) approach is not a 'black or white' approach, as suggested by Hirschman (1982), however.

According to Scitovsky (1976), there is a high level of satisfaction, which takes place when arousal decreases after achieving the first sensation of satisfaction - pleasure-by consuming a good for the first time. There is a second sensation of satisfaction associated with the consumption of the same good again, which is a secondary reward. This secondary 
reward means comfort, but it is a higher level of comfort than the satisfaction generated by consuming the same good regularly. Hence, pleasure is the higher satisfaction a good can generate for the consumer; thereafter, comfort is felt but there are different levels of comfort. When comfort is achieved, the consumer starts the search for more pleasurable goods. Therefore, Hirschman (1982) precisely points out the pleasure-comfort dichotomy in Scitovsky's theory. However, it is not a 'black or white' perspective, as suggested.

\section{Building bridges}

This section is focused strictly on the main goal of this study: to complement Veblen's conspicuous consumer approach with Scitovsky's neuropsychological perspective. The content of Sections Two and Three makes clear that both Veblen and Scitovsky recognize that inner impulses are not in the core of consumers as decision makers. In this core, according to both Veblen and Scitovsky, are the relationships between each consumer and the world around her/him. A complementary approach between Veblen's conspicuous consumer and Scitovsky's neuropsychology of consumer decision making is based on their perspective of how relationships between consumer and their environment are established. Veblen's approach relies on social learning associated with the role of habits and institutions in conspicuous consumers' decision making. There is no direct pressure from inner impulses to consume but the content of habits and institutions introduce to the conspicuous consumer the pressure to acquire goods by the concepts they carry. Scitovsky's perspective relates to arousal and different levels of satisfaction - comfort and pleasure - generated by the acquisition of different goods. Complementing Veblen's logic with Scitovsky's logic involves inserting neuropsychology into the institutional perspective of the conspicuous consumer.

As highlighted in Section Two, in Veblen's theory, the acquisition of a good is a result of the appropriation process. A first step toward a complementary approach to both theories requires the insertion of arousal and levels of satisfaction in the logic of the appropriation process. Hence, someone could assume that, following Scitovsky's approach, appropriation means there is a connection between an inner impulse and a good because of the 
arousal that good carries. Different goods would mean different levels of arousal, which culminates in different levels of satisfaction. As previously stressed, high arousal results in higher levels of satisfaction - pleasure - and lower levels of arousal culminates in lower levels of satisfaction - comfort. However, for this logic to be true, the arousal must have been associated with the physical meaning of the goods. That is not the case for Veblen's conspicuous consumer. For Scitovsky's neuropsychology to complement Veblen's conspicuous consumer, it is essential to take into consideration that the arousal trigger is the institutionally created concepts of goods.

Taking the concepts of goods into consideration, an appropriation is an association between an inner impulse and a concept of a good as stated by the arousal that concept holds. Pleasure and comfort are related to arousal of concepts of goods. The arousal of concepts of goods is created institutionally. This must be so because the satisfaction felt by Veblen's conspicuous consumers, who acquire such concepts of goods, is created institutionally. Hence, from a Veblenian perspective, arousal is also a social issue. In the Veblenian theory, the socialization process by which consumers learn how to identify aroused concept of goods relies on habits and institutions. Hence, by addressing the complementary theoretical perspective, the Veblenian notion of habit is a key issue - because of its peculiarity. Fortunately, it is possible to affirm that Scitovsky's notion of habit fits Veblenian habits, as the following quotation indicates.

Many of our wants are not innate and biologically determined, but are acquired by learning. Once they are acquired, and once their ability to give satisfaction has been learned, they also become habitual and create drives to maintain or repeat the newly learned satisfactions (Scitovsky, 1976, p.67, emphasis in the original).

For Scitovsky (1976), every organism with a central nervous system is a creature of habits. In addition, Scitovsky affirms that habit building is a central issue of decision making (Scitovsky, 1976). Furthermore, Scitovsky's psychological perspective of habits does not fit Dewey's criticism that habit is simply repetition; moreover, the social issues of habits are taken into account by Scitovsky.

Given these considerations, the importance of a conspicuous consumer's understanding of the content of institutions and habits becomes a central topic. The conspicuous consumer must understand how institutionalized and habitual procedures form aroused concept of goods that culminate in a higher satisfaction if consumed. Consumers must understand what the 
aroused concepts of goods mean. Nevertheless, the acquisition of aroused concepts of goods is just a part of the decision-making process. Another, extremely important part is the path taken by the conspicuous consumer in the institutional and habitual logic of concepts of goods. This is because the consumer's place in a stratified society influences whether an aroused concept of a good is a novelty to her/him, that is, whether the concept of the good has been acquired by her/him before. As Section Three stressed, novelty gives rise to higher levels of satisfaction; however, to attain pleasure, a level of familiarity is demanded.

In a Veblenian approach, institutions and habits introduce such familiarity to the conspicuous consumer. Otherwise, the aroused concepts of goods would imply higher levels of excitement because they are unknown. In this case, the arousal is associated with novelty but it is not novelty in the conspicuous consumer's logic. For the conspicuous consumer, novelty cannot be the absolutely-unknown but never-acquired concepts of goods that are only partly unknown. To highlight more details about this neuropsychological perspective of Veblen's conspicuous consumer, it is essential to take into account the logic introduced by institutions and habits for the consumer, that is, the emulative logic and consequent place of the leisure class in the Veblenian conspicuous consumer's decision making. However, first let us take into consideration the neuropsychological perspective of the socialization process.

For instance, Berlyne (1973) affirms that the potential arousal in acquiring concepts of goods is introduced to consumers by the decision-making environment. In addition, Hebb (1955) stresses that arousal comes from objects of the external world instead of the inner elements of the decision maker. Consequently, both Berlyne's and Hebb's approaches support the connection between Veblen's and Scitovsky's studies, as suggested by this study. However, neither Berlyne nor Hebb clearly analyze the socialization process of consumers. As for Scitovsky, such analysis relies on his theory rather than neuropsychology per se. Scitovsky (1972) supports emulation by affirming that consumers face various pressures that make them satisfied with the tastes of others rather than their own. Hence, Scitovsky (1972) stresses that the socialization process plays a key role in what consumers understand their taste for goods to be. This discussion guides us to the neuropsychological perspective of the role of emulating the leisure class for Veblen's conspicuous consumer. 
Considering Scitovsky's neuropsychology, the concepts of goods that conspicuous consumers emulate hold high arousal. A key issue to bridge Veblen's conspicuous consumption and Scitovsky's neuropsychology is the meaning of the concepts of goods consumed by the leisure class. This is because the leisure class, by the biased traditions contained in habits and institutions, introduces to consumers the concepts of goods that carry higher status in a society. Goods consumed by the leisure class imply a source of arousal that supports the emulative logic of the majority of conspicuous consumers in a society. ${ }^{10}$

Following this logic, emulation is guided by arousal; in other words, arousal is associated with the status content of the concepts of goods. The capacity to acquire aroused goods means the consumer survives social selection. In emulative logic, not only concepts of goods consumed by the leisure class can be aroused; concepts of goods consumed by higher classes than that of the consumer are also aroused. This is associated with the acquisition of goods in a group. For Scitovsky (1976), the feeling of belonging to a group plays a key role in consumers' decision making. Pleasure would be the result of mutual stimulation as stimulation for novelty comes from interaction with others (Scitovsky, 1976). These others are members of groups with which conspicuous consumers would like to be identified. The survival of conspicuous consumers in social selection depends on their acceptance as members of upper social classes, in Veblen's theory. The acceptance ticket would be the acquisition of concepts of goods, as stated, by these upper classes. However, once the concepts of the goods of the upper classes are consumed, arousal associated with consuming these goods decreases.

By emulation, consumers learn which goods should be included in their decision making, as stressed by institutionally established arousal. Pleasure and its absence are not physical outcomes - displeasure is also

10 For Scitovsky (1972), the leisure classes of most previous societies generated socio-values that supported unequal specialization in employment and leisure time. Societies inherit not only art, architecture, literature, and so on, but also the arts and skills of consumption. This is despite the fact that Scitovsky (1972) makes a clear reference to the leisure class and to the fact that it evolves in a society. There is no mention of how this evolution takes place. In addition, Scitovsky (1972) does not quote Veblen's conceptualization of the leisure class. However, Scitovsky (1985) affirms that the consumer decision-making approach of Veblen has room for social wants and conspicuous consumption. Scitovsky (1985) does not provide large methodological considerations for how his neuropsychological economic perspective can be connected to a conspicuous consumption study, but he highlights the existence of bridges between those approaches, as this study intended to address. 
a mental phenomenon. Displeasure is the result of a failure in emulative logic, and in this case, the consumer can understand the institutionally evolved concepts of goods but cannot satisfy her/his impulse with the related concepts of goods (e.g., because of a lack of financial resources). In this case, comfort can be found in keeping the acquisition of the concepts of the goods as before. Consequently, the level of satisfaction of acquiring a concept of a good depends on the previous experiences of the consumer, as previously stressed in this section. It is important to take into account that, for Scitovsky (1976), the comfort-pleasure distinction is not black or white logic. A secondary high level of satisfaction exists due to acquiring a concept of good one more time. This secondary high level of satisfaction is a possible higher comfort. Thereafter, comfort declines gradually according to the repetition of the acquisition of concepts of goods.

Considering pleasure, acquiring the concepts of goods consumed by the leisure class is not the only way for consumers to feel pleasure and does not imply pleasure is generated every time those concepts of goods are acquired. Veblen's society is a stratified society trickled down from the leisure class. Consumers emulate concepts of goods associated with the social class they would like to be identified as part of. Therefore, every time that a consumer is able to acquire concepts of goods of a higher social class than she/he was used to, pleasure is felt. These concepts of goods mean novelty for the consumer. The possibility of appropriation for the first time is pleasurable, despite the fact that such concepts of goods are not associated with the status of the leisure class. There is also satisfaction in holding a position in the emulative social logic, but this satisfaction is lower than achieving a social class for the first time, like when a consumer maintains the acquisition of concepts of goods and comfort is the result.

This neuropsychological perspective of Veblen's conspicuous consumer highlights a key issue, that is, the only way that a consumer can maintain the pleasure of acquiring concepts of goods is to keep rising in social mobility. To continue to be a member of the leisure class means comfort. Perhaps, the more important issue that this study is able to stress is that in terms of satisfaction, social ascension means more for the conspicuous consumer than being a member of the leisure class.

There is another possible result for consumers' emulative acquisition of concepts of goods. A consumer can find herself/himself in a situation in which the concepts of goods acquired hold less status than before. In 
this case, there is an emulative backspace, and the consumer is in a lower social class than before. If an emulative backspace occurs, dissatisfaction known as discomfort is felt. In this case, the consumer strongly fails in social selection. Consumers face dissatisfaction from losing or lacking status - this process is understood by the consumer as immiserating consumption. As status loss results in discomfort, consumers look to support their status to avoid the pain of not achieving satisfaction.

For Scitovsky (1985), even members of the leisure class can try to find pleasure instead of comfort. According to Scitovsky (1985), as soon as other social classes are able to acquire the concepts of goods consumed by the leisure class, the latter would find another way to be distinguished by what is consumed. ${ }^{11}$ Following Veblen's logic, this would occur by increasing the level of conspicuousness of the concepts of goods consumed by the leisure class, which would be a new source of pleasure. Hence, taking consumption into account, Scitovsky (1976) shares Veblen's key issues of societies' evolution, namely, the capacity to yearn for new concepts of goods. Summing up, despite the social dimension, satisfaction is a personal feeling attached to each consumer's path and place in a society, and this satisfaction is a comfort or pleasure, depending on the ascension or maintenance of social class. Hence, the satisfaction of consuming the same good diverges according to which consumer is considered.

\section{Final comments}

Veblen's conspicuous consumption approach relies on the significance of habits and institutions in decision making. This study introduces some extensions of psychological elements associated with Veblen's conspicuous consumer in order to highlight other associated issues. Those other elements are related closely to how conspicuous consumers include habits and institutions in their decision making and acquire goods accordingly. This study explored how: (i) inner impulses to acquire goods are associated to habits and institutions of the external world; (ii) Veblen's conspicuous consumer can achieve different levels of satisfaction through acquisition of goods; (iii) Veblen's conspicuous consumer looks for the acquisition 
of concepts of goods rather than goods themselves; (iv) satisfaction as a result of acquiring concepts of goods varies according to the path of the conspicuous consumer in a society; (v) the higher level of satisfaction that a conspicuous consumer can achieve is the pleasure of consuming concepts of goods associated with a higher social class than she/he was used to; and (vi) the satisfaction of consuming concepts of goods associated with a higher social class than she/he was used to is stronger than the satisfaction achieved by members of the leisure class. Clearly, this study does not exhaust the possibilities of the association between psychology and Veblen's conspicuous consumer. The present study is limited to specific segments, namely, American pragmatism and the neuropsychology of Scitovsky's approach.

\section{References}

ALMEIDA, F. Thorstein Veblen and Albert Bandura: A Modern Psychological Reading of the Conspicuous Consumer. Journal of Economic Issues, v.48, n.1, p.109-122, 2014.

ALMEIDA, F. The Psychology of Early Institutional Economics: The Instinctive Approach of Thorstein Veblen's Conspicuous Consumer Theory. Economia, v.16, n.2, p.226-234, 2015.

ARGYROUS, G.; SETHI, R. The Theory of Evolution and the Evolution of Theory: Veblen's Methodology in Contemporary Perspective. Cambridge Journal of Economics, v.20, p.475495, 1996.

BERLYNE, D. Conflict, Arousal, and Curiosity. New York: McGraw-Hill, 1960.

BERLYNE, D. The Vicissitudes of Aplopathematic and Thelematoscopic Pneumatology (or the Hydrography of Hedonism). In: BERLYNE, D.; MADSEN, K. Pleasure, Reward, Preference: Their Nature, Determinants, and Role in Behavior. New York: Academic Press, 1973, p.1-33.

BERLYNE, D.; MADSEN, K. Pleasure, Reward, Preference: Their Nature, Determinants, and Role in Behavior. New York: Academic Press, 1973.

BROWN, D. Thorstein Veblen in the Twenty-First Century. Cheltenham: Edward Elgar, 1998.

CORDES, C. Veblen's "Instinct of Workmanship", its Cognitive Foundations, and Some Implications for Economic Theory. Journal of Economic Issues, v.39, n.1, p.1-20, 2005.

DEWEY, J. How We Think. New York: DC Heath \& Co Publishers, 1910a.

DEWEY, J. The Experimental Theory of Knowledge. In: MCDERMOTT, J. The Philosophy of John Dewey, p.175-193. Chicago and London: The University of Chicago Press, [1910b] 1981.

DEWEY, J. Human Nature and Conduct: An Introduction to Social Psychology. New York: DC Heath \& Co Publishers, 1921.. 
DEWEY, J. The Lost Individual. In: MCDERMOTT, J. The Philosophy of John Dewey, p.598608. Chicago and London: The University of Chicago Press, [1930] 1981.

DEWEY, J. Art as Experience. In: HAACK, S.; LANE, R. Pragmatism, Old \& New, p.423-441. New York: Prometheus Books, [1934] 2006.

DEWEY, J. Culture and Human Nature. In: MCDERMOTT, J. The Philosophy of John Dewey, p.679-696. Chicago and London: The University of Chicago Press, [1939] 1981.

EDGELL, S.; TILMAN, R. The Intellectual Antecedents of Thorstein Veblen: A Reappraisal. Journal of Economic Issues, v.23, n.4, p.1003-1026, 1989.

FRIEDMAN, J.; MCCABE, A. Preferences or Happiness? Tibor Scitovsky's Psychology of Human Needs. Critical Review, v.10, n.4, p.471-480, 1996.

HAACK, S.; LANE, R. Pragmatism, Old \& New. New York: Prometheus Books, 2006.

HEBB, D. Drives and the C.N.S. (Conceptual Nervous System). The Psychological Review, v.66, n.4, p. 243-254, 1955.

HIRSCHMAN, A. Shifting Involvements: Private interest and public action. New Jersey: Princeton University Press, 1982.

HODGSON, G. The Approach of Institutional Economics. Journal of Economic Literature, v.36, p.166-192, 1998.

HODGSON, G. The Evolution of Institutional Economics: Agency, structure and darwinism in American Institutionalism. London: Routledge, 2004.

JAMES, W. The Principles of Psychology: Volume 1. New York: Cosimo, 2007 [originally published in 1890a].

JAMES. W. The Principles of Psychology: Volume 2. New York: Cosimo, 2007 [originally published in 1890b].

LATSIS, J. Veblen on the Machine Process and Technological Change. Cambridge Journal of Economics, v.34, p.601-615, 2009.

MCDERMOTT, J. The Philosophy of John Dewey. Chicago and London: The University of Chicago Press, 1981.

PEIRCE, C. Some consequences of four incapacities. In: HAACK, S.; LANE, R. (Eds.). Pragmatism, Old \& New. New York: Prometheus Books, p.69-105, 2006 [1868].

PEIRCE, C. The Fixation of Belief. In: HAACK, S.; LANE, R. (Eds.). Pragmatism, Old \& New. New York: Prometheus Books, p.107-126, 2006 [1877].

RAMSTAD, Y. Veblen's Propensity to emulation: Is it passé? In: BROWN, D. (Ed.). Thorstein Veblen in the Twenty-First Century. Cheltenham: Edward Elgar, 1998.

RUTHERFORD, M. The Institutionalist Movement in American Economics, 1918-1947: Science and Social Control. Cambridge: The Cambridge University Press, 2011.

SCITOVSKY, T. Notes on the Producer Society. In: SCITOVSKY, T. (Ed.). Human desire and economic satisfaction: Essays on the frontiers of Economics. New York: New York University Press, p.47-69, 1986 [1972].

SCITOVSKY, T. The Joyless Economy: The psychology of human satisfaction. New York: Oxford University Press, 1992 [1976]. 
SCITOVSKY, T. The Desire for Excitement in Modern Society. In: SCITOVSKY, T. (Ed.). Human desire and economic satisfaction: Essays on the frontiers of Economics. New York: New York University Press, p.128-135, 1986 [1981].

SCITOVSKY, T. How to Bring Joy into Economics. In: SCITOVSKY, T. (Ed.). Human Desire and Economic Satisfaction: Essays on the Frontiers of Economics. New York: New York University Press, p.183-203, 1986 [1985].

SCITOVSKY, T. Human Desire and Economic Satisfaction: Essays on the Frontiers of Economics. New York: New York University Press, p.183-203, 1986.

SEN, A. Rationality, Joy and Freedom. Critical Review, v.10, n.4, p.551-594, 1996.

SHIPMAN, A. Lauding the Leisure Class: Symbolic Content and Conspicuous Consumption. Review of Social Economy, v.62, n.3, p.277-289, 2004.

TRIGG, A. Veblen, Bourdieu, and Conspicuous Consumption. Journal of Economic Issues, v.35, n. 1, p.99-115, 2001.

TWOMEY, P. Reviving Veblenian Economic Psychology. Cambridge Journal of Economics, v.22, p.433-448, 1998.

VEBLEN, T. Why is Economics Not an Evolutionary Science? Cambridge Journal of Economics, v.22, p.403-414, 1998 [originally published in 1898 in The Quarterly Journal of Economics, July: p.373-397].

VEBLEN, T. The Theory of the Leisure Class. Oxford: Oxford University Press, 2007 [1899].

VEBLEN, T. The Limitations of Marginal Utility. Journal of Political Economy, v.17, n.9, p.620636, 1909.

VEBLEN, T. The Instinct of Workmanship and the State of the Industrial Arts. New York: Cosimo, 2006 [1914].

VEBLEN, T. The Vested Interests and the Common Man. New York: Cosimo, 2005 [1919].

WALLER, W. Reconsidering Thorstein Veblen's Use of Instincts. In: Conferência Anual da EAEPE, 08 de novembro de 2013, University of Paris-Nord. Paris, França, November 8, 2013.

\section{About the authors}

Felipe Almeida - felipe.almeida@ufpr.br

Universidade Federal do Paraná, Curitiba, PR.

\section{About the article}

Submission received on August 10, 2015. Approved for publication on April 26, 2016. 